\title{
Indikasi Bullying Fisik pada Siswa SD dan Implikasinya Terhadap Pendidikan Akhlak Menurut Tuntunan Agama
}

\author{
Dadang Kurnia' ${ }^{1}$ Ani Nur Aeni ${ }^{2}$
}

1,2PGSD UPI Kampus Sumedang

J. Mayor Abdurachman No. 211 Sumedang

'Email: hajidadangkurnia@gmail.com

2Email: aninuraeni@upi.edu

\begin{tabular}{l} 
ABSTRACT \\
\hline Cases of bullying among elementary school \\
students are high. Therefore, it needs to get \\
attention. This study reveals an indication of \\
physical bullying that occurs in elementary \\
students and its implications for moral education \\
according to the guidance of Religion. The \\
method used is survey and literature study with \\
the qualitative approach. Participants involved a \\
number of 55 elementary school teachers in \\
Cirebon district and the city of Cirebon. The \\
results showed that: 1) almost half of the physical \\
bullying indication occurred in primary school \\
with the highest percentage is in punching and \\
pinching behavior, while the smallest \\
percentage is strangling behavior; 2) moral \\
education can be a therapy to change the bad \\
behavior of physical bullying and can be used as \\
a preventive effort.
\end{tabular}

Keywords: indication, bullying, moral education, bad behavior, noble character.

\begin{abstract}
Kasus bullying di kalangan siswa SD cukup tinggi, untuk itu perlu mendapatkan perhatian. Penelitian ini mengungkap indikasi bullying fisik yang terjadi pada siswa SD dan implikasinya terhadap pendidikan akhlak menurut tuntunan Agama. Metode yang digunakan adalah survei dan studi literatur dengan pendekatan kualitatif. Partisipan yang terlibat sejumlah 55 guru SD di wilayah Cirebon, meliputi kabupaten dan kota. Hasil penelitian menunjukkan bahwa: 1) hampir setengahnya indikasi bullying fisik terjadi di SD dengan persentase tertinggi ada pada perilaku memukul dan mencubit, sedangkan persentase terkecil pada perilaku mencekik; 2) pendidikan akhlak dapat menjadi terapi untuk merubah perilaku buruk bullying fisik dan dapat dijadikan sebagai upaya pencegahannya.
\end{abstract}

Kata Kunci: indikasi, bullying, pendidikan akhlak, perilaku buruk, akhlak karimah.

How to Cite: Kurnia, D., \& Aeni, A. (2018). Indikasi Bullying Fisik pada Siswa SD dan Implikasinya Terhadap Pendidikan Akhlak Menurut Tuntunan Agama. Mimbar Sekolah Dasar, 5(2), 97-115. doi:http://dx.doi.org/10.17509/mimbarsd.v5i2.11641.

PENDAHULUAN Istilah bullying sering terdengar akhir-akhir ini melalui media, baik media massa, elektronik, maupun internet, walaupun kasus bullying ini bukan kasus baru, tetapi kasus yang sudah lama terjadi dan angkanya tinggi. Menurut Sufriani dan Sari (2017) bahwa kasus bullying dari tahun 2011 sampai tahun 2014 saja tercatat sebanyak 1.480 kasus. Bullying menjadi topik hangat yang dibicarakan ketika tersiar berita korban bullying memilih mengakhiri hidupnya dengan bunuh diri, karena depresi atau ketika korban bullying meninggal dunia. Sebuah studi yang dikutip oleh Burnstein Klomek, dkk (Santrock, 2012, p. 383) menyatakan bahwa pelaku dan korban bullying di masa remaja cenderung mengalami depresi dan berniat untuk bunuh diri. Bullying merupakan tindakan intimidasi yang mengakibatkan korban menderita bahkan dapat berujung kematian, dengan demikian bullying merupakan suatu tindakan kekerasan 
Dadang Kurnia \& Ani Nur Aeni, Indikasi Bullying Fisik pada Siswa SD...

atau agresi, sebagimana yang dinyatakan oleh Batsche \& Knoff (1994) bahwa bullying adalah bentuk penyalahgunaan hubungan yang mencakup tindakan agresi dimana satu atau lebih siswa secara fisik dan atau secara psikologis melecehkan korban yang lebih lemah.

Bullying dapat terjadi dimana saja selama adanya interaksi antar manusia, di sekolah, di masyarakat, di rumah ataupun di tempat lainnya. Namun sungguh ironis jika bullying ini terjadi di sekolah, karena sekolah merupakan institusi pendidikan tempat para siswa dididik oleh pendidik untuk menjadi orang terdidik. Berdasarkan hasil penelitian Kustanti (2015) dinyatakan bahwa sebagian besar siswa pada semua tingkat pendidikan pernah mendapatkan gangguan dari teman. Siswa yang paling banyak mendapat gangguan adalah siswa SD ( $\mathrm{n}=78 ; 82,98 \%$ ). Perlakuan tidak menyenangkan paling sering terjadi di kelas dan halaman sekolah. Pada mahasiswa perlakuan tidak menyenangkan paling sering terjadi di kantin dan di luar kampus.

Bullying dapat terjadi karena beberapa faktor diantaranya karena faktor harga diri, kepribadian, kelvarga, sekolah dan teman sebaya. Hasil penelitian yang dilakukan oleh Fitria dan Auli (2017) menyatakan bahwa harga diri, kepribadian, keluarga, sekolah dan teman sebaya memiliki hubungan yang signifikan terhadap perilaku bullying. Hubungan yang terjadi sifatnya negatif, dimana jika harga diri tinggi maka perilaku bullying yang terjadi rendah dan jika harga diri rendah maka bullying yang terjadi tinggi. Demikian pula dengan kepribadian. Kepribadian berkontribusi besar pada ciri khas perilaku anak-anak dalam situasi bullying. Keluarga, sekolah dan teman sebaya juga menunjukkan adanya hubungan terhadap perilaku bullying.

Bullying dapat terjadi pada fisik dan non fisik. Coloraso (2007) membagi jenis bullying kedalam tiga bentuk, yaitu verbal bullying, psysical bullying, dan relational bullying. Sedangkan dalam Tim Yayasan Sejiwa (2008, p. 2) disebutkan bahwa bullying itu terdiri dari tiga bentuk, yaitu bullying fisik, bullying non fisik, dan bullying mental/psikologis. Murphy menyebutkan bahwa bullying dapat terjadi secara langsung (direct bullying) ataupun tidak langsung (indirect bullying). Selain jenis-jenis bullying tersebut, muncul pula istilah cyberbullying, yaitu istilah yang digunakan pada saat seorang anak atau remaja mendapat perlakuan tidak menyenangkan seperti dihina, diancam, dipermalukan, disiksa atau menjadi bulanbulanan oleh anak atau remaja lain dengan menggunakan teknologi internet atau teknologi digital interaktif maupun teknologi mobile (Fitriani, 2017). Kim (Adila, 2009, p. 57) menyebutkan bahwa bullying dapat terjadi dalam bentuk verbal, psikologis, dan fisik.

Bullying fisik adalah tindakan bullying yang bersentuhan langsung dengan fisik 
korbannya, seperti memukul, menendang dan lain-lain. Coloraso (2007) menyebutkan bahwa bullying fisik ini bentuk bullying yang paling dapat terlihat dan paling mudah diidentifikasi. Berdasarkan hasil penelitian yang dilakukan oleh Dewi, Hasan, dan Mahmud (2016) tentang perilaku bullying yang terjadi di SD dinyatakan bahwa lebih dari 50\% siswa SD pernah mengalami kejadian bullying fisik di sekolah, dan hanya $37 \%$ yang menjawab tidak pernah.

Mengingat angka bullying di SD tinggi, maka kasus bullying di SD harus menjadi perhatian. Hasil penelitian yang dikutip oleh Fitria dan Auli (2016) bahwa di Indonesia didapatkan $10-60 \%$ siswa melaporkan mendapat ejekan, cemoohan, pengucilan, pemukulan tendangan ataupun dorongan sedikitnya sekali dalam seminggu. Sebagai wujud perhatian terhadap perilaku bullying ini maka dilakukan penelitian lanjutan tentang bullying pada siswa SD. Penelitian kali ini secara umum bertujuan untuk menemukan indikasi bullying fisik oleh siswa SD terhadap siswa yang lainnya (sesama teman). Penelitian ini hanya mengungkap indikasi dari perilaku bullying, artinya mengungkap tandatanda perilaku bullying, khususnya bullying fisik. Secara rinci masalah yang diteliti dirumuskan ke dalam poin pertanyaan berikut:

1. Bagaimana indikasi bullying fisik oleh siswa SD kepada siswa lainnya (sesama teman)?

2. Bagaimana implikasi bullying pada siswa SD terhadap pendidikan akhlak menurut tuntunan agama?

\section{METODE}

Penelitian ini menggunakan pendekatan kualitatif dengan teknik pengumpulan data berupa survei dan studi literatur. Teknik survei digunakan untuk menjawab rumusan nomor 1, sedangkan teknik studi literatur digunakan untuk menjawab rumusan masalah nomor 2. Untuk survei digunakan Instrumen angket, sedangkan untuk studi literatur digunakan buku-buku, dan sumber rujukan lain yang relevan dengan penelitian ini.

Partisipan yang terlibat sejumlah 55 guru Sekolah Dasar (SD) yang mengajar sebagai guru kelas di kelas $1,2,3,4,5,6$ dan guru olahraga serta guru PAI di SD negeri dan swasta di wilayah Cirebon, yang meliputi kabupaten dan kota Cirebon. Adapun karakteristik partisipan dapat dilihat pada tabel 1.

Tabel 1. Karakteristik Partisipan

\begin{tabular}{rrrrrrrrr}
\hline \multicolumn{4}{c}{ Jenis Kelamin } & \multicolumn{7}{c}{ Usia } \\
\hline LK & PR & Jumlah & $<25$ & $25-30$ & $31-35$ & $36-40$ & $>40$ & Jumlah \\
28 & 26 & 55 & 0 & 16 & 8 & 12 & 19 & 55 \\
$50,9 \%$ & $49,1 \%$ & $100 \%$ & $0 \%$ & $29,1 \%$ & $14,5 \%$ & $21,8 \%$ & $34,6 \%$ & $100 \%$ \\
\hline
\end{tabular}


Dadang Kurnia \& Ani Nur Aeni, Indikasi Bullying Fisik pada Siswa SD...

Teknik pengolahan data dilakukan secara kualitatif, dengan menghitung alternatif jawaban yang diberikan oleh partisipan (ya/tidak), lalu dipersentasekan dengan rumus berikut.

$$
\%=\frac{\text { Jumlah jawaban responden }}{\text { Jumlah responden seluruhnya }} \times 100
$$

Setelah diperoleh jumlah \% tersebut kemudian diinterpretasikan ke dalam kriteria berikut ini.

Tabel 2. Kriteria Penafsiran

\begin{tabular}{ll}
\hline$\%$ & Tafsiran \\
\hline$x=0$ & Tak ada satupun \\
$0<x<25$ & Sebagian kecil \\
$25<x<50$ & Hampir setengahnya \\
$x=50$ & Setengahnya \\
$50<x<75$ & Sebagian besar \\
$75<x<100$ & Hampir seluruhnya \\
$x=100$ & Seluruhnya \\
\hline
\end{tabular}

(Sumber: Aeni, 2017)

HASIL

\section{Indikasi Bullying Fisik oleh Siswa SD Kepada Siswa Lainnya (Sesama Teman)}

Berdasarkan pengolahan data angket diperoleh hasil sebagai berikut.

Tabel 3. Indikasi Bullying Fisik Pada Siswa SD

\begin{tabular}{|c|c|c|c|c|c|c|c|}
\hline \multirow{2}{*}{ No } & \multirow{2}{*}{ Indikasi } & \multicolumn{2}{|c|}{ Jawaban Ya } & \multicolumn{2}{|c|}{ Jawaban tidak } & \multicolumn{2}{|c|}{ Total } \\
\hline & & $\mathrm{Jml}$ & $\%$ & Jml & $\%$ & $\mathrm{Jml}$ & $\%$ \\
\hline 1. & $\begin{array}{l}\text { Di sekolah pernah ada siswa yang memukul } \\
\text { siswa lainnya }\end{array}$ & 36 & 65,5 & 19 & 34,5 & 55 & 100 \\
\hline 2. & $\begin{array}{l}\text { Di sekolah pernah ada siswa yang menjewer } \\
\text { siswa lainnya }\end{array}$ & 29 & 52,7 & 26 & 47,3 & 55 & 100 \\
\hline 3. & $\begin{array}{l}\text { Di sekolah pernah ada siswa yang mencubit } \\
\text { siswa lainnya }\end{array}$ & 36 & 65,5 & 19 & 34,5 & 55 & 100 \\
\hline 4. & $\begin{array}{l}\text { Di sekolah pernah ada siswa yang meninju } \\
\text { siswa lainnya }\end{array}$ & 29 & 52,7 & 26 & 47,3 & 55 & 100 \\
\hline 5. & $\begin{array}{l}\text { Di sekolah pernah ada siswa yang mendorong } \\
\text { siswa lainnya }\end{array}$ & 35 & 63.6 & 20 & 36.4 & 55 & 100 \\
\hline 6. & $\begin{array}{l}\text { Di sekolah pernah ada siswa yang menendang } \\
\text { siswa lainnya }\end{array}$ & 24 & 43,6 & 31 & 56,4 & 55 & 100 \\
\hline 7. & $\begin{array}{l}\text { Di sekolah pernah ada siswa yang menyeret } \\
\text { kepala siswa lainnya }\end{array}$ & 23 & 41,8 & 32 & 58,2 & 55 & 100 \\
\hline 8. & $\begin{array}{l}\text { Di sekolah pernah ada siswa yang melempar } \\
\text { benda kepada siswa lainnya }\end{array}$ & 32 & 58,2 & 23 & 41,8 & 55 & 100 \\
\hline 9. & $\begin{array}{l}\text { Di sekolah pernah ada siswa yang menjemur } \\
\text { siswa lainnya }\end{array}$ & 12 & 21,8 & 43 & 78,2 & 55 & 100 \\
\hline 10. & $\begin{array}{l}\text { Di sekolah pernah ada siswa yang menyuruh } \\
\text { siswa lainnya untuk lari lari }\end{array}$ & 15 & 27,3 & 40 & 72,7 & 55 & 100 \\
\hline 11. & $\begin{array}{l}\text { Di sekolah pernah ada siswa yang menyuruh } \\
\text { siswa lainnya untuk push up }\end{array}$ & 12 & 21,8 & 43 & 78,2 & 55 & 100 \\
\hline 12. & $\begin{array}{l}\text { Di sekolah pernah ada siswa yang menyuruh } \\
\text { siswa lainnya untuk berdiri di depan kelas }\end{array}$ & 9 & 16,4 & 46 & 83,6 & 55 & 100 \\
\hline 13. & $\begin{array}{l}\text { Di sekolah pernah ada siswa yang menginjak } \\
\text { siswa lainnya }\end{array}$ & 21 & 38,2 & 34 & 61,8 & 55 & 100 \\
\hline 14. & $\begin{array}{l}\text { Di sekolah pernah ada siswa yang mengunci } \\
\text { siswa lainnya di sebuah ruangan }\end{array}$ & 14 & 25,5 & 41 & 74,5 & 55 & 100 \\
\hline 15. & $\begin{array}{l}\text { Di sekolah pernah ada siswa yang menggigit } \\
\text { siswa lainnya }\end{array}$ & 20 & 36,4 & 35 & 63,6 & 55 & 100 \\
\hline 16. & $\begin{array}{l}\text { Di sekolah pernah ada siswa yang mencakar } \\
\text { siswa lainnya }\end{array}$ & 26 & 47,3 & 29 & 53,7 & 55 & 100 \\
\hline 17. & $\begin{array}{l}\text { Di sekolah pernah ada siswa yang memalak } \\
\text { siswa lainnya }\end{array}$ & 28 & 50,9 & 27 & 49,1 & 55 & 100 \\
\hline
\end{tabular}




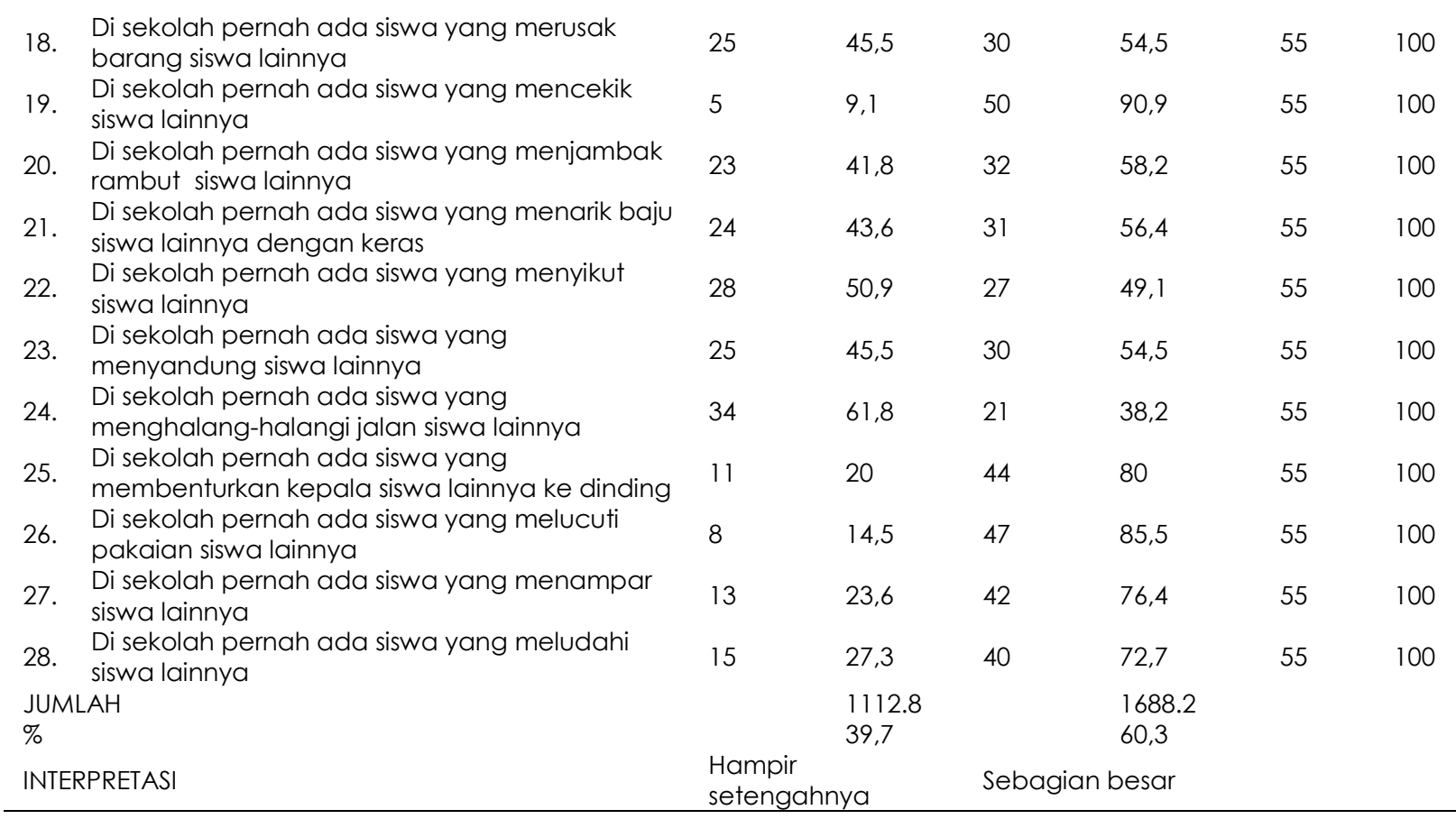

Implikasi Bullying Fisik pada Siswa SD Terhadap Pendidikan Akhlak Menurut Tuntunan Agama

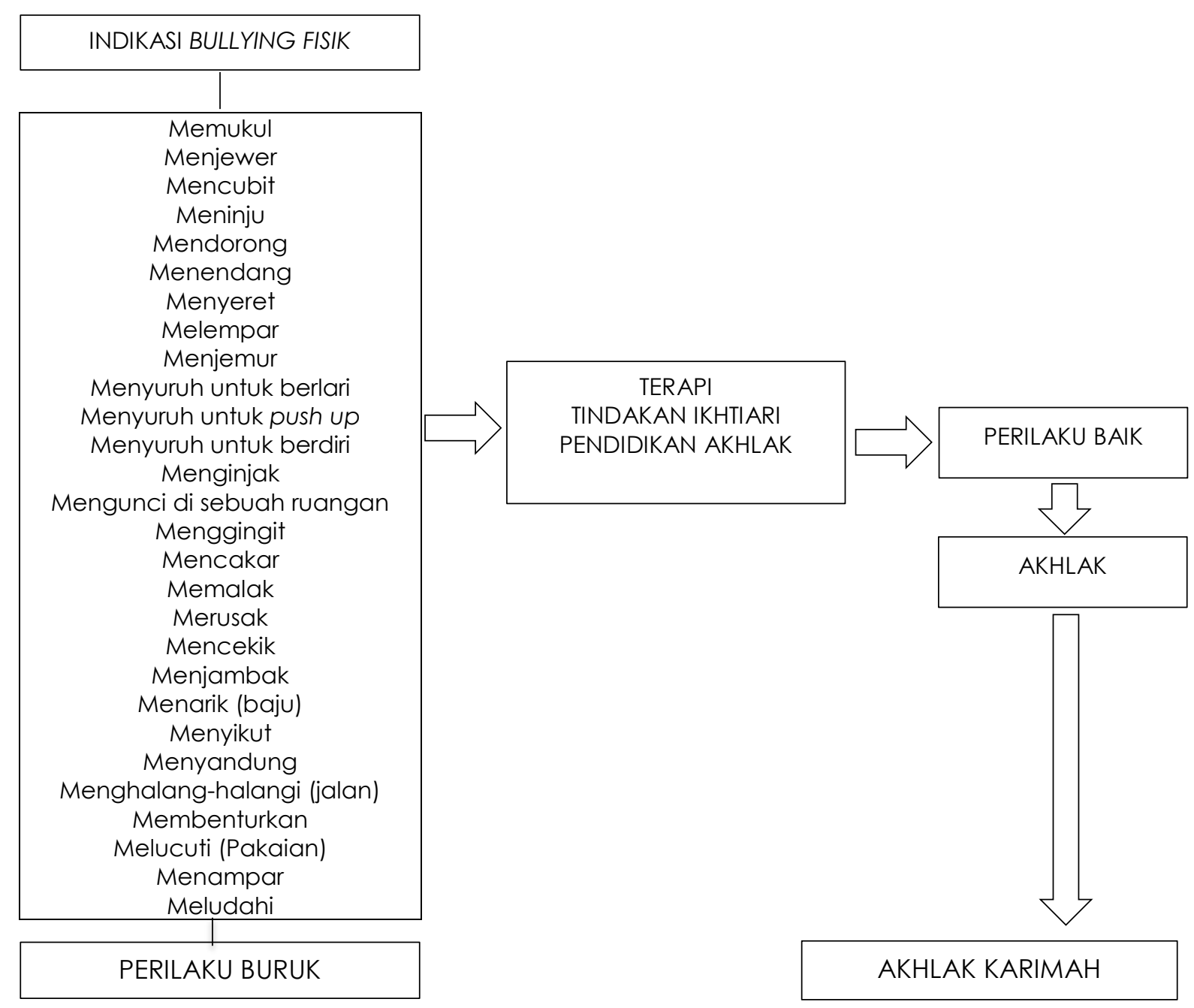

Gambar 1. Implikasi Bullying Fisik terhadap Pendidikan Akhlak 
Dadang Kurnia \& Ani Nur Aeni, Indikasi Bullying Fisik pada Siswa SD...

\section{PEMBAHASAN}

Indikasi Bullying Fisik oleh Siswa SD Kepada Siswa Lainnya (Sesama Teman)

Dari tabel. 3 diketahui bahwa dari 28 indikator bentuk bullying fisik, semua indikator muncul, artinya semua perilaku bullying fisik pernah dilakukan oleh siswa SD terhadap siswa lainnya (sesama teman), walaupun dengan frekuensi yang berbeda dari setiap indikator tersebut. Bullying fisik menurut Tim Yayasan Sejiwa (2008, p. 2) adalah tindakan bullying yang dilakukan oleh pelaku secara langsung bersentuhan dengan fisik korbannya. Yang termasuk kepada bullying fisik yang pernah dilakukan oleh siswa SD adalah sebagai berikut.

\section{Memukul}

Dalam penelitian ini diperoleh data sebesar 65,5\%, artinya perilaku memukul ini sebagian besar muncul dan pernah terjadi pada siswa SD. Menurut Tim Penyusun Kamus Besar Bahasa Indonesia (2005. p. 905) memukul didefinisikan sebagai mengenakan suatu benda yang keras atau berat dengan kekuatan, sehingga memukul pada kasus bullying adalah mengenakan tangan baik dengan alat maupun tanpa alat (benda) ke badan dengan kekuatan. Istilah memukul ini dalam konsep pendidikan Islam yang berkaitan dengan pendidikan orang tua terhadap anak berdasarkan hadits perintah mengajarkan shalat kepada anak, diperbolehkan dengan catatan tidak menyakiti dan bukan memukul pada tempat yang tidak diperbolehkan seperti muka, berdasarkan Hadits "Jika salah seorang dari kalian memerangi (berkelahi) maka hendaknya dia menjauhi (menghindari) wajah." (HR. Bukhori dalam al-Asqalani, 2010), namun memukul dalam kasus bullying tidak diperbolehkan karena akan menyakiti dan bertujuan bukan untuk mendidik, tetapi untuk merendahkan dan melukai, sebagaimana tersirat dalam pengertian bullying menurut Coloroso (2007) bullying merupakan tindakan intimidasi yang dilakukan secara berulang-ulang oleh pihak yang lebih kuat terhadap pihak yang lebih lemah dilakukan dengan sengaja dan dilakukan untuk melukai korbannya secara fisik maupun emosional.

\section{Menjewer}

Dari hasil penelitian ini diperoleh data $52,7 \%$, artinya perilaku menjewer ini sebagian besar terjadi di SD yang dilakukan oleh siswa SD kepada sesama temannya. Menurut Tim Penyusun Kamus Besar Bahasa Indonesia (2005. p. 473) menjewer adalah menarik (memilin) telinga, jadi istilah menjewer ini sasarannya khusus untuk telinga. Menjewer tidak diperbolehkan karena membahayakan fungsi telinga, walaupun tidak meninggalkan bekas, namun menjewer yang keras selain akan mengakibatkan rasa sakit juga berbahaya, karena pada telinga banyak mengandung titik syaraf yang banyak. Pada titik titik syaraf tersebut dapat dilakukan pijat refleksi untuk melakukan penyembuhan penyakit, sebaliknya jika titik-titik syaraf tersebut 
terganggu maka akan menyebabkan kerusakan pada bagian tubuh tertentu. Dampak negatif dari menjewer menurut Fuadi (2014) adalah dapat menimbulkan traumatik dan merusak harga diri anak.

\section{Mencubit}

Dalam penelitian ini diperoleh data 65,5\%, artinya indikasi mencubit terjadi pada sebagian besar siswa SD. Menurut Tim Penyusun Kamus Besar Bahasa Indonesia (2005. p. 221) mencubit adalah menjepit dengan ibu jari dan telunjuk atau jari lain (pipi, tangan, paha, dan sebagainya), jadi pada mencubit ini alat yang digunakan adalah jari, sementara sasarannya adalah anggota tubuh. Mencubit dapat meninggalkan bekas, terutama mencubit yang dilakukan dengan keras akan menyebabkan luka fisik.

\section{Meninju}

Dalam penelitian ini diketahui 52,7\%, artinya sebagian besar siswa pernah melakukan indikasi bullying dengan meninju temannya. Menurut Tim Penyusun Kamus Besar Bahasa Indonesia (2005. p. 1198) meninju diartikan sebagai memukul dengan kepalan tangan. Meninju dilakukan tanpa alat, karena meninju dilakukan dengan kepalan tangan. Meninju anggota badan berbahaya, terutama jika area yang ditinju adalah anggota badan yang syarat dengan uraturat syaraf atau pada bagian tubuh yang disebutkan dalam infokabayan (2011) berikut ini: a) Perut, karena akan menyebabkan lambung terluka sehingga mengganggu pencernaan, dan dapat menyebabkan muntah darah.

b) Punggung, karena dapat menyebabkan terputusnya tulang belakang, dan dapat menyebabkan muntah darah.

c) Dada, karena akan menyebabkan patah tulang rusuk, paru-paru rusak, dan dapat menyebabkan kematian.

d) Dagu, karena akan menyebabkan tergesernya tulang rahang, dan menimbulkan rasa sakit yang hebat.

e) Hidung, karena akan menyebabkan pendarahan yang disebabkan oleh rusaknya tulang rawan, dan akan mengganggu pernapasan.

f) Telinga, karena akan menyebabkan cairan di dalam telinga bergoyang dan membuat pusing akhirnya pingsan.

g) Mata, karena akan menyebabkan kerusakan pada mata, bahkan menimbulkan kebutaan.

h) Kepala, karena akan menyebabkan gegar otak, dan menyebabkan kematian.

i) Belakang leher, karena akan menyebabkan sistem saraf tulang belakang putus sehingga meyebabkan anggota badan kaku dan tidak dapat melakukan apa-apa.

j) Alat kelamin, karena akan menimbulkan rasa sakit yang hebat dan jika terjadi pada buah pelir, dapat mengakibatkan kemandulan.

k) Jakun, karena akan menyebabkan rusaknya sistem pernafasan, 
Dadang Kurnia \& Ani Nur Aeni, Indikasi Bullying Fisik pada Siswa SD...

pencernaan dan rusaknya pita suara, dan dapat menyebabkan kematian.

\section{Mendorong}

Pada penelitian ini diperoleh hasil sebesar $63,6 \%$, artinya sebagian besar perilku mendorong ini dilakukan oleh siswa SD dan diindikasikan sebagai bentuk bullying fisik. Jika perilaku ini dilakukan berulangulang maka sudah dapat dikatakan sebagai bullying, karena suatu perilaku menyakitkan itu dapat disebut sebagai bullying jika adanya faktor pengulangan, sebagimana yang disebutkan oleh Olweus (1993, p. 9) bahwa bullying adalah sebuah bentuk ekspresi aksi negatif yang diulang oleh seorang pelajar atau sekelompok pelajar terhadap yang lainnya. Dalam Kamus Besar Bahasa Indonesia (Tim penyusun, 2005, p. 274) mendorong diartikan sebagai menolak dari bagian belakang atau bagian depan. Yang dimaksud mendorong dalam kasus bullying adalah mendorong badan.

\section{Menendang}

Berdasarkan hasil penelitian ini diketahui bahwa 43,6\% perilaku ini pernah terjadi di $\mathrm{SD}$, artinya hampir setengahnya perilaku menendang ini pernah dilakukan oleh siswa SD kepada sesama temannya, dalam Kamus Besar Bahasa Indonesia (Tim penyusun, 2005, p. 1171) mengartikan menendang dengan menyepak; mendepak (dengan kaki), yang dimaksud menendang dalam kasus bullying ini adalah mendepak anggota badan dengan kaki. Jika ada anak menendang, mendorong, memukul jangan dianggap tindakan yang normal, karena menurut Gichara (2018. p. 8), bahwa jika tindakan menendang, mendorong, dan memukul dibiarkan akan memunculkan perkelahian. Jika hal ini berulang kali dilakukan oleh anak maka akan menyebabkan anak biasa berperilaku buruk, dan akan mendominasi teman lainnya dalam permainan atau pergaulan. Perilaku buruk ini terjadi karena dipengaruhi oleh pertumbuhan otak dan kemampuan tubuhnya jika tidak segera diatasi dapat membahayakan orang lain. Perilaku buruk yang dilakukan secara berulang kali kepada orang lain ini disebut dengan bullying sebagaimana yang dinyatakan oleh Righby (1996) "bullying adalah tekanan berulang secara fisik atau psikis oleh orang atau kelompok orang yang lebih kuat terhadap yang lebih lemah.

\section{Menyeret}

Pada penelitian ini diperoleh data bahwa perilaku menyeret angkanya 41,8\%, artinya hampir setengahnya perilaku ini terjadi. Kamus Besar Bahasa Indonesia (Tim penyusun, 2005, p. 1049) mengartikan kata menyeret dengan memaksa ikut (turut); menarik dengan paksa; membawa (orang) dengan paksa. Hal ini menandakan adanya indikasi bullying di SD, karena menurut Juwita (2016) perilaku itu disebut bullying lebih kepada faktor pemaksaan, dalam hal ini ia mengatakan bahwa bullying adalah bentuk perilaku berupa pemaksaan atau usaha menyakiti 
secara fisik maupun psikologis terhadap seseorang atau sekelompok orang yang lebih lemah oleh seseorang atau sekelompok orang yang mempersiapkan diri sebagai kelompok yang lebih kuat.

\section{Melempar Benda}

Dari penelitian ini diketahui $58,2 \%$ indikasi bullying ini muncul, artinya sebagaian besar siswa SD melakukan tindakan ini kepada temannya. Siswa yang melakukan tindakan melempar benda ini biasanya dipengaruhi oleh beberapa faktor, yang paling dominan adalah karena faktor keluarga khususnya orang tua, dalam hal ini Rghby (1993) mengatakan bahwa pelaku bullying cenderung memiliki hubungan yang buruk dengan orang tuanya ketimbang anak-anak yang tidak terlibat.

\section{Menjemur}

Dalam penelitian ini diperoleh angka yang tidak terlalu besar untuk tindakan menjemur, yaitu sebesar $21,8 \%$, artinya hanya sebagian kecil saja indikasi bullying ini terjadi di SD. Tindakan menjemur adalah memanaskan (mengeringkan) di bawah sinar panas matahari (Tim penyusun $\mathrm{KBBI}, 2005$, p. 467). Tindakantindakan bullying ini dilakukan oleh para pelaku bulling dikarenakan memiliki latar belakang: mudah putus asa, emosi tak terkendali, impulsif atau dominan, menunjukkan kekerasan dengan berbagai cara. Para pelaku bullying melakukan tindakan yang merugikan orang lain baik secara fisik maupun non fisik, karena dipengaruhi oleh beberapa faktor sebagaimana yang dinyatakan oleh Sugijokanto (2014) yaitu pengaruh keluarga, pengaruh teknologi dan televisi, paksaan atau ejekan teman-teman, pernah menjadi korban bullying dan tidak ada tindakan untuk menghentikannya.

\section{Menyuruh untuk Lari-lari}

Penelitian ini berhasil menemukan data sebesar $27,3 \%$ perilaku ini terjadi, artinya hanya sebagian kecil saja indikasi bullying ini muncul pada siswa SD yang dilakukan kepada sesama temannya. Namun walaupun angkanya kecil bukan berarti dapat diabaikan, karena jika tindakan ini terjadi dan dialami oleh siswa SD akan menimbulkan dampak negatif. Srabstein (Santrock, 2012. p. 383) mengungkapkan bahwa pelaku, korban, atau pelaku sekaligus korban bullying berdampak pada kesehatannya, seperti sakit kepala, sulit tidur, dan merasa cemas.

\section{Menyuruh untuk Push-Up}

Dari penelitian ini diperoleh data 21,8\% indikasi ini ada di SD, artinya hanya sebagian kecil saja tindakan ini terjadi pada siswa SD. Walaupun angkanya kecil namun tetap saja tindakan ini tidak dapat ditolerir. Jika hal ini terjadi di sekolah maka menjadi tanggung jawab guru untuk mengatasinya. Untuk menghindarkan hal ini terjadi, maka guru harus mampu membangun komunikasi yang baik dengan siswa, harus dapat memahami aspek psikologis siswa. Hal ini mencerminkan guru yang profesional, 
Dadang Kurnia \& Ani Nur Aeni, Indikasi Bullying Fisik pada Siswa SD...

yaitu memahami bidang psikologi pendidikan (Fahdini, Mulyadi, Suhandani, \& Julia. 2014). Pemahaman terhadap aspek psikologis siswa merupakan bagian dari psikologi pendidikan.

\section{Menyuruh untuk Berdiri di Depan Kelas}

Dalam penelitian ini terungkap $16,4 \%$ indikasi ini muncul, artinya perilaku ini hanya sebagian kecil terjadi pada siswa SD. Tindakan menyuruh untuk berdiri di depan kelas ini diindikasikan sebagai bullying fisik yang dilakukan oleh pelaku, karena pelaku merasa dominan dan merasa lebih kuat dari pada korban. Perilaku tersebut memperlihatkan perilaku yang kejam (Giwangsa, Ikhsan, Aminah, 2017).

\section{Menginjak}

Penelitian ini menemukan data sebesar $38,2 \%$ perilaku ini muncul pada siswa SD, Tim Penyusun Kamus Besar Bahasa Indonesia (2005. p. 434) mengartikan menginjak dengan meletakkan kaki pada sesuatu, yang dimaksud dalam kasus bullying adalah meletakkan kaki pada anggota badan dengan maksud menyakiti dan menyebabkan korban jadi menderita. Menginjak anggota badan membahayakan terhadap fisik, selain itu dampak psikologis yang muncul dari bullying (Olweus, 1999).

\section{Mengunci di Sebuah Ruangan}

Hasil yang diperoleh dari penelitian ini menunjukkan angka $25,5 \%$, artinya hanya sebagian kecil saja tindakan ini terjadi pada siswa SD. angka yang kecil ini menandakan bahwa tindakan ini pernah terjadi. Jika tindakan keji dan mengerikan ini terjadi pada siswa SD maka akan menimbulkan trauma (Harijono, 2015).

\section{Menggigit}

Dari penelitian ini diperoleh hasil sebesar $36,4 \%$ indikasi ini muncul, artinya hampir setengahnya perilaku ini dilakukan oleh siswa SD kepada sesama temannya. Menurut Tim Penyusun Kamus Besar Bahasa Indonesia (2005. p. 363) menggingit adalah menjepit (mencekam dan sebagainya) dengan gigi, Perlu dibedakan perilaku menggingit pada anak sebagai sebuah kebiasaan dengan perilaku menggingit sebagai bulling. Dalam kasus bullying, menggigit ini dilakukan sebagai bentuk agresif dengan ciri-ciri yang diungkapkan oleh Olweus (1993) yaitu: a) dimaksudkan untuk membahayakan dan mengganggu, b) dilakukan secara berulang dari waktu ke waktu, c) ketidakseimbangan kekuatan, yang dominan terhadap yang lainnya.

\section{Mencakar}

Pada penelitian ini ditemukan sebesar 47,3\% perilaku ini muncul, artinya hampir setengahnya indikator ini ada pada siswa SD. Dalam Kamus Besar Bahasa Indonesia (Tim penyusun, 2005, p. 188) mencakar diartikan dengan menggaruk dengan cakar; melukai dengan cakar. Cakar adalah kuku yang panjang dan tajam. Bullying ini diindikasikan pernah terjadi di sekolah dasar baik negeri maupun swasta, 
karena bullying muncul dimana-mana. Bullying tidak memilih umur dan jenis kelamin kepada korbannya. Menurut Astuti (2018) yang menjadi korban biasanya adalah anak yang lemah, pemalu, pediam dan special (cacat, tertutup, pandai cantik, atau punya ciri tubuh tertentu) yang dapat menjadi bahan ejekan.

\section{Memalak}

Melalui penelitian ini terungkap bahwa 50,9\% perilaku ini muncul pada siswa siswa, artinya setengahnya siswa SD melakukan tindakan ini. Kamus Besar Bahasa Indonesia (Tim penyusun, 2005, p. 815) mengartikan kata memalak dengan meminta secara paksa; memeras. Istilah memalak selalu dikonotasikan dengan vang. Sebagai tindakan bullying memalak dilakukan oleh pelaku bullying dengan meminta sejumlah vang kepada korban. Dari hasil penelitian tersebut menandakan bahwa memalak ini terjadi di sekolah, khususnya di SD. Menurut hasil penelitian Yayasan Semai Jiwa Amani (dalam Purnama, 2010, p. 22) bullying merupakan persoalan yang kerap sekali muncul di sekolah, sehingga menyebabkan korban tidak mau lagi pergi ke sekolah.

\section{Merusak Barang}

Dalam penelitian ini diungkapkan sebanyak $45,5 \%$ perilaku ini terjadi di SD. Perilaku merusak barang disebut juga dengan tindakan agresi. Menurut Chomaria (2013. p. 149) "agresi ini merupakan bentuk luapan emosi anak yang tidak terbendung kemarahannya". Penyebab anak melakukan agresi dengan merusak barang karena anak pernah melihat atau menyaksikan tindakan tersebut dilakukan oleh orang lain yang dekat dan sering dijumpai oleh dirinya, terutama orang yang sangat berpengaruh dalam hidupnya, misalnya orang tua. Orang tua menjadi figur sentral bagi anak dalam mencontoh tindakan baik dan buruk. Oleh karena itu keteladanan orang tua menjadi faktor utama bagi anak dalam membentuk karakter anak sebagaimana yang dinyatakan oleh Aeni (2017) bahwa "Pendidikan keteladanan sangat efektif terhadap pembentukan karakter anak".

\section{Mencekik}

Dari penelitian ini diperoleh data bahwa perilaku mencekik hanya terjadi sebesar $9,1 \%$, artinya hanya sebagian kecil saja perilaku ini terjadi pada siswa SD oleh siswa SD. Menurut Tim Penyusun Kamus Besar Bahasa Indonesia (2005. p. 363) mencekik adalah memegang dan mencekam leher (merih) sehingga yang dipegang dan dicekam tidak dapat bernapas. Mencekik ini dilakukan oleh pelaku bullying untuk menindas temannya. Hal ini terjadi karena beberapa faktor sebagaimana yang dinyatakan oleh Chomaria (2013, p. 157-158), yaitu: melihat model, menutupi kelemahan, pelarian dari ketidakharmonisan orang tua, fasilitas yang terbatas di lingkungannya, dan pernah menjadi korban. 
Dadang Kurnia \& Ani Nur Aeni, Indikasi Bullying Fisik pada Siswa SD...

\section{Menjambak Rambut}

Dalam penelitian ini terungkap 41,8\% perilaku ini terjadi di SD, artinya, hampir setengahnya indikasi ini muncul pada siswa SD. Kamus Besar Bahasa Indonesia (Tim penyusun, 2005, p. 455) mengartikan istilah menjambak dengan merenggut (rambut). Menjambak rambut sebagai bentuk dari bullying dapat terjadi pada siapapun sebagai sasaran/korban bullying, namun menurut Theo dan Watiek (2016) biasanya yang menjadi sasaran utamanya adalah anak-anak yang dianggap lemah, tidak berdaya, pencemas, terlihat berbeda (fisik, ras, cara berpakaian, dan lain-lain), pendatang baru, penakut, atau anak yang rendah diri.

\section{Menarik Baju dengan Keras}

Penelitian ini menemukan sebesar $43,6 \%$ tindakan ini dilakukan oleh siswa SD, artinya hampir setengahnya siswa SD melakukan tindakan ini kepada temannya. Siswa yang melakukan hal ini berarti siswa yang memiliki perilaku tercela. Rusyan (Tt. p. 115) menyebutkan bahwa perilaku tercela adalah perilaku yang tidak sesuai dengan kaidah-kaidah dan norma-norma yang telah ditentukan agama manapun yang berlaku di masyarakat.

\section{Menyikut}

Dari hasil penelitian ini terungkap bahwa menyikut ini terjadi di SD dengan angka $50,9 \%$, artinya lebih dari setengah perilaku ini dilakukan oleh siswa SD kepada sesama temannya. Dalam Kamus Besar Bahasa Indonesia (Tim penyusun, 2005, p. 1063) menyikut diartikan dengan menyandung, menyinggung (mendesak) dengan sikut. Secara etika dan tatakrama, menyikut termasuk kepada perbuatan yang tidak sopan. Di sekolah guru harus mengajarkan dan mencontohkan tatakrama yang baik kepada siswa. Tata krama itu tetap harus diterapkan kepada orang yang lebih tua, sesama, dan yang lebih muda. Menurut Zuriah (2007) memang melakukan tata krama dengan teman sebaya agak sulit karena mereka merupakan teman sederajat dan sehari-hari berjumpa sehingga sering lupa memperlakukannya dengan sopan santun yang baik, namun demikian tetap hal ini harus dilakukan.

\section{Menyandung}

Dari penelitian ini diperoleh hasil bahwa indikasi menyandung ini muncul sebesar $45,5 \%$, artinya hapir setengahnya indikasi bullying ini terjadi di SD. Kamus Besar Bahasa Indonesia (2005, p. 993) menyebutkan bahwa yang dimaksud menyandung adalah menyentuh sesuatu dengan tidak sengaja (tentang kaki). Tindakan menyandung membahayakan keselamatan korban, pada intinya perilaku-perilaku yang diindikasikan sebagai bullying membahayakan kepada fisik dan psikologis korban. Menurut teori bullying dalam psikologi (dosenpsikologi.com, 2018) dinyatakan "Keinginan untuk mencederai /desire to hurt)", artinya tindakan tersebut sengaja dilakukan untuk mencederai dan melukai 
korban, sehingga jika berhasil akan menimbulkan rasa senang pada diri pelaku menyaksikan penderitaan korbannya.

\section{Menghalang-halangi Jalan}

Dari penelitian ini diperoleh hasil sebesar $61,8 \%$ indikasi ini muncul, artinya sebagian besar indikasi ini terjadi di SD. Tindakan ini dilakukan dengan adanya intimidasi kepada korban baik dilakukan oleh perorangan atau kelompok orang. Jika hal ini terjadi di sekolah dan disaksikan oleh guru, maka guru harus memiliki rasa tangguh jawab untuk menyelesaikannya dan berusaha untuk melakukan tidakan pencegahan supaya tidak terjadi lagi pada korban dan pelaku berikutnya. Salah satu cara yang dapat dilakukan menurut Astuti (2008) adalah bantu anak untuk menumbuhkan self-esteem (harga diri) yang baik. Anak yang memiliki selfesteem yang baik akan mampu menghargai dirinya dan orang lain, berani, optimis, dan percaya diri.

\section{Membenturkan Kepala}

Penelitian menghasilkan data bahwa sebesar $44 \%$ indikasi ini terjadi di SD. Perilaku ini jika dilakukan secara berulang dan menyakitkan orang lain, maka sudah tergolong kepada perilaku bullying. Hal ini sebagaimana dinyatakan oleh Olweus (2006) bahwa bullying merupakan suatu perilaku negatif berulang yang bermaksud menyebabkan ketidakseimbangan atau menyakitkan oleh orang lain, baik satu atau beberapa orang secara langsung terhadap seseorang yang tidak dapat melawannya.

\section{Melucuti Pakaian}

Dari penelitian ini diperoleh data bahwa indikasi ini hanya muncul sebesar $14,5 \%$, artinya hanya sebagian kecil tindakan ini dilakukan di SD. namun walaupun persentasenya kecil, tetap tindakan ini harus dihindari dan dicegah. Jika hal ini terjadi maka tindakan yang harus dilakukan menurut Astuti (2008) adalah tidak perlu melawan pelaku dengan berkelahi karena akan membuat kondisi tidak aman, tetapi lebih baik mencari bantuan kepada orang yang dewasa.

\section{Menampar}

Dalam penelitian ini diungkapkan sebesar $23,6 \%$ perilaku ini muncul, artinya sebagian kecil saja hal ini terjadi di SD. Dalam Kamus Besar Bahasa Indonesia (Tim penyusun, 2005, p. 1131) menampar diartikan dengan memukul dengan telapak tangan. Istilah menampar biasanya dikonotasikan untuk anggota badan pipi. Bullying dalam bentuk apapun harus dicegah supaya tidak terjadi, terutama di sekolah dasar. Espalge (2014) mengatakan bahwa bullying akan dapat dikurangi jika sistem tempat dimana bullying itu muncul tidak memberikan imbalan apapun dan justru memberikan denda atau hukuman setiap perilaku bullying muncul. 
Dadang Kurnia \& Ani Nur Aeni, Indikasi Bullying Fisik pada Siswa SD...

\section{Meludahi}

Dari penelitian ini diperoleh data 27,3\% perilaku ini terjadi di SD, artinya hanya sebagian kecil indikasi bullying ini terjadai pada siswa SD yang dilakukan oleh sesama temannya. Dalam Kamus Besar Bahasa Indonesia (Tim penyusun, 2005, p. 686) meludah (berludah) pada sesuatu. Ludah adalah air yang keluar dari mulut atau disebut juga dengan air liur. Dalam kasus bullying meludahi berarti berludah pada badan (fisik) seseorang. Jika hal ini disaksikan oleh guru di sekolah, khususnya di SD, anak harus diajari kemampuan manajemen konflik dengan jalan damai dan harus juga ditanamkan nilai-nilai anti kekerasan (Giwangsa, Ikhsan,. \& Aminah, 2017).

Keduapuluh delapan indikator tersebut termasuk kepada perilaku buruk yang harus dihindarkan dan tidak boleh dilakukan. Indikator-indikator tersebut dilakukan sebagai bentuk intimidasi terhadap orang lain (Wikipedia, 2018), dan dipandang sebagai bagian dari kekerasan dan perilaku agresif (Batsche \& Knoff, 1994).

Keduapuluh indikator yang telah disebutkan di atas merupakan bentuk bullying fisik. Perilaku-perilaku yang telah disebutkan pada indikator tersebut dilakukan oleh pelaku bullying terhadap orang yang dianggap kurang kuat, sebagaimana yang dinyatakan oleh Santrock (2012, p. 383) bahwa bullying adalah perilaku verbal datau fisik yang dimaksudkan untuk menyerang orang lain yang kurang kuat.

Dari penjelasan kedelapan puluh delapan indikator bullying diatas, dapat disimpulkan bahwa perilaku-perilaku tersebut sasarannya adalah fisik korban yang dilakukan oleh pelaku bullying dengan tindakan fisik. Tindakan-tindakan fisik tersebut memiliki karakteristik tersendiri, yaitu:

Tabel 5. Karakteristik Perilaku Bullying Fisik

\begin{tabular}{|c|c|c|c|c|}
\hline \multirow[t]{2}{*}{ No } & \multirow[t]{2}{*}{ Perilaku } & \multirow{2}{*}{$\begin{array}{l}\text { Karakteristik anggota } \\
\text { badan/alat/benda/tempat } \\
\text { yang digunakan }\end{array}$} & \multicolumn{2}{|c|}{ Sasaran } \\
\hline & & & Fisik & lainnya \\
\hline 1. & Memukul & $\begin{array}{l}\text { Tangan } \\
\text { (pakai alat atau tanpa alat) }\end{array}$ & $\begin{array}{l}\text { Seluruh anggota } \\
\text { badan }\end{array}$ & $\begin{array}{l}\text { Benda lainnya selain } \\
\text { badan }\end{array}$ \\
\hline 2. & Menjewer & tangan & telinga & - \\
\hline 3. & Mencubit & $\begin{array}{l}\text { Jari tangan (ibu jari dan jari } \\
\text { telunjuk) }\end{array}$ & $\begin{array}{l}\text { Seluruh anggota } \\
\text { badan }\end{array}$ & - \\
\hline 4. & Meninju & Kepalan tangan & $\begin{array}{l}\text { Seluruh anggota } \\
\text { badan }\end{array}$ & $\begin{array}{l}\text { Benda lainnya selain } \\
\text { badan }\end{array}$ \\
\hline 5. & Mendorong & Badan, tangan & badan & $\begin{array}{l}\text { Benda lainnya selain } \\
\text { badan }\end{array}$ \\
\hline 6. & Menendang & kaki & badan & $\begin{array}{l}\text { Benda lainnya selain } \\
\text { badan }\end{array}$ \\
\hline 7. & Menyeret & tangan & badan & $\begin{array}{l}\text { Benda lainnya selain } \\
\text { badan }\end{array}$ \\
\hline 8. & Melempar & tangan & badan & $\begin{array}{l}\text { Benda lainnya selain } \\
\text { badan }\end{array}$ \\
\hline 9. & Menjemur & Sinar matahari & badan & $\begin{array}{l}\text { Benda lainnya selain } \\
\text { badan }\end{array}$ \\
\hline
\end{tabular}




\begin{tabular}{|c|c|c|c|c|}
\hline 10. & $\begin{array}{l}\text { Menyuruh untuk } \\
\text { berlari }\end{array}$ & kaki & badan & - \\
\hline 11. & $\begin{array}{l}\text { Menyuruh untuk } \\
\text { push up }\end{array}$ & Tangan, kaki, badan & badan & - \\
\hline 12. & $\begin{array}{l}\text { Menyuruh untuk } \\
\text { berdiri }\end{array}$ & kaki & badan & - \\
\hline 13. & Menginjak & kaki & badan & $\begin{array}{l}\text { Benda lainnya selain } \\
\text { badan }\end{array}$ \\
\hline 14. & $\begin{array}{l}\text { Mengunci di } \\
\text { sebuah ruangan }\end{array}$ & Ruangan tertutup & badan & - \\
\hline 15. & Menggingit & gigi & badan & $\begin{array}{l}\text { Benda lainnya selain } \\
\text { badan }\end{array}$ \\
\hline 16. & Mencakar & Kuku tangan & badan & $\begin{array}{l}\text { Benda lainnya selain } \\
\text { badan }\end{array}$ \\
\hline 17. & Memalak & Uang/yang bersifat materi & badan & - \\
\hline 18. & Merusak & $\begin{array}{l}\text { Tangan (pakai alat atau } \\
\text { tanpa alat) }\end{array}$ & badan & $\begin{array}{l}\text { Benda lainnya selain } \\
\text { badan }\end{array}$ \\
\hline 19. & Mencekik & tangan & leher & - \\
\hline 20. & Menjambak & tangan & rambut & - \\
\hline 21. & Menarik (baju) & Tangan & Badan & $\begin{array}{l}\text { Benda lainnya selain } \\
\text { badan }\end{array}$ \\
\hline 22. & Menyikut & sikut & badan & - \\
\hline 23. & Menyandung & kaki & kaki & - \\
\hline 24. & $\begin{array}{l}\text { Menghalang- } \\
\text { halangi (jalan) }\end{array}$ & Jalan, tempat yang dilalui & badan & - \\
\hline 25. & Membenturkan & tangan & kepala & - \\
\hline 26. & Melucuti (Pakaian) & tangan & badan & Baju pada badan \\
\hline 27. & Menampar & Telapak tangan & $\begin{array}{l}\text { Anggota badan } \\
\text { (pipi) }\end{array}$ & - \\
\hline 28. & Meludahi & ludah & Anggota badan & $\begin{array}{l}\text { Benda lainnya selain } \\
\text { badan }\end{array}$ \\
\hline
\end{tabular}

Implikasi Bullying pada Siswa SD Terhadap Pendidikan Akhlak Menurut Tuntunan Agama

Indikasi bullying fisik sebagimana yang telah disebutkan pada tabel 3, tergolong kepada perilaku buruk. Perilaku adalah tanggapan atau reaksi individu terhadap rangsangan atau lingkungan (KBBI, 2005, p. 859). Psikologi memandang perilaku manusia (human behavior) sebagai reaksi yang dapat bersifat sederhana maupun bersifat kompleks (Azwar, 2008. p. 9). Perilaku buruk merupakan sifat tercela. Dalam tuntunan agama Islam orang yang memiliki sifat tercela dan buruk berarti memiliki aklhak yang buruk (aklak sayyiah) atau akhlak madzmumah (aklak tercela). Sebenarnya secara istilah kurang tepat untuk menyebut perilaku buruk itu dengan sebutan akhlak, karena akhlak hanya dimaksudkan untuk menyebutkan sejumlah tindakan yang baik. Namun secara kebahasaan menurut Ali (2007), akhlak bisa baik atau buruk tergantung kepada tata nilai yang dipakai sebagai landasannya, sebagimana juga Sauri (2011) menyebutkan bahwa secara umum akhlak Islam dibagi menjadi dua, yaitu akhlak mulia (al-akhlak al-mahmudah/alkarimah) dan akhlak tercela (al-akhlak madzmuma/al-qobihah). Akhlak mulia adalah yang harus diterapkan dalam kehidupan sehari-hari, sedangkan akhlak tercela adalah akhlak yang harus dihindarkan dan dijauhi dan jangan dipraktikkan dalam kehidupan sehari-hari. 
Dadang Kurnia \& Ani Nur Aeni, Indikasi Bullying Fisik pada Siswa SD...

Perilaku buruk sebagai indikasi bullying fisik dapat dihindarkan dan dicegah, terutama untuk siswa SD, yang secara tahap perkembangan moral dan kognitif masih mengalami perkembangan sebagaimana teori perkembangan moral dan kognitif yang dinyatakan oleh Piaget (Syah, 2007. p. 39) dan sangat mungkin untuk berubah. Pada usia SD sangat memungkinkan untuk menanamkan nilainilai baik supaya terwujud siswa yang berakhlak karimah (mulia). Upaya membentuk akhlak mulia ini dapat dilakukan melalui pendidikan akhlak. Pendidikan akhlak merupakan sebuah upaya sadar yang dilakukan sebagai proses pembinaan budi pekerti anak sehingga menjadi budi pekerti yang mulia (akhlaq karimah). Proses tersebut tidak terlepas dari pembinaan kehidupan beragama peserta didik secara totalitas.

Ibn Miskawih (Aeni, 2014, p. 53) mendefinisikan pendidikan akhlak sebagai upaya ke arah terwujudnya sikap batin yang mampu mendorong secara spontan lahirnya perbuatan-perbuatan yang bernilai baik dari diri seseorang. Menurut Majid \& Andayani (2012) pendidikan akhlak bisa dikatakan sebagai pendidikan moral dalam diskursus pendidikan Islam. Tujuan pendidikan akhlak adalah terbentuknya karakter positif dalam perilaku anak didik. Demikian pula Aeni (2014) menyepadankan pendidikan akhlak dengan pendidikan moral, pendidikan budi pekerti, pendidikan karakter, pendidikan nilai, dan pendidikan dunia afektif.

Pelaku bullying harus diterapi melalui pendidikan akhlak dengan cara dibina melalui proses pembinaan keagamaan secara totalitas sesuai dengan tuntunan agama. Yang dimaksud tuntunan agama di sini adalah agama Islam, jadi pendidikan akhlak harus berdasarkan pada sumber Al-Quran dan hadits, artinya ukuran baik dan buruk perilaku mausia itu berdasarkan pada kedua sumber tersebut.

Perilaku yang buruk dapat diterapi untuk menjadi lebih baik, karena secara prinsip, akhlak itu adalah suatu tindakan ikhtiari (Tim Dosen PAl, 2003). Tindakan ikhtiari adalah tindakan yang digerakkan oleh usaha (keras). Tindakan ikhtiari ini berbeda dengan tindakan alami. Perilaku buruk bukan sifat alami atau pembawaan sejak lahir. Dalam konsep Islam setiap anak yang dilahirkan dalam keadaan fitrah. Fitrah di sini dapat diartikan bahwa setiap anak lahir dengan perilaku yang baik, namun dalam perjalanan hidupnya fitrah akhlak baik ini ada yang terjaga ataupun tidak. Penyebab terjadinya perubahan ini dikarenakan banyak faktor, salah satunya adalah kesadaran teistik (kesadaran beragama).

Untuk merubah perilaku buruk diperlukan usaha sungguh sungguh dan keras dengan menyadarkannya pada keberagamaan (teistik). Dalam kesadaran 
beragama ini ditunjukkan bagaimana seharusnya siswa itu berperilaku kepada khalik dan makhluk. Akhlak kepada khalik adalah akhlak kepada Allah sebagai pencipta, dan akhlak kepada makhluk meliputi makhluk dalam bentuk manusia dan bukan manusia. Akhlak kepada manusia meliputi diri sendiri, tetangga, masyarakat, teman. Akhlak kepada bukan manusia meliputi flora, fauna, dan sebagainya (Anshari, 1993. p. 29).

Pendidikan akhlak yang diberikan kepada siswa dalam upaya mengatasi bullying lebih difokuskan pada akhlak sesama manusia. Menurut tim dosen PAI (2008, p. 148) akhlak terhadap sesama manusia ini bertujuan untuk menciptakan kondisi dan lingkungan sosial yang harmonis, penuh kedamaian sehingga kondusif bagi perkembangan jiwa setiap individu, dan mencegah dari gejolak-gejolak sosial akibat terjadinya ketidakpuasan dari tindakan pihak lain.

Pada pendidikan akhlak sebagai upaya mencegah dan mengatasi bullying pada siswa SD, anak diajarkan berakhlak kepada sesama teman, akhlak kepada yang lebih tua, dan akhlak kepada yang lebih muda bagaimana seharusnya mereka bersikap dan berperilaku kepada teman yang seusia, seatas, dan sebawah darinya. Siswa diajarkan bagaimana cara menghormati, menghargai, mempunyai belas kasihan kepada yang lemah (Suresman, 2006. p. 77). Akhlak berdasarkan tuntunan agama Islam telah ditunjukkan dalam beberapa surat dan ayat, misalnya perintah berbuat kebaikan (Q.S. 16: 90) perintah meniggalkan keburukan (Q.S. 21: 35), perintah untuk berkasih sayang (Q.S. 48: 29), perintah meninggalkan permusuhan (Q.S. 41: 34), perintah untuk tidak marah (Q.S. 42: 36-37) dan masih banyak lagi ayat-ayat lainnya yang berkaitan dengan akhlak.

Proses pembinaan keagamaan melalui pendidikan akhlak ini sebagai bentuk terapi bagi para pelaku dan korban bullying dan sebagai upaya untuk pencegahan supaya kasus bullying tidak terjadi di sekolah. Melalui pendidikan akhlak ini akan melahirkan siswa siswa yang berperilaku baik, yaitu siswa yang berakhlak dengan akhlak karimah (akhlak mulia).

\section{SIMPULAN}

Berdasarkan hasil penelitian diperoleh simpulan bahwa: (1) $39,7 \%$ dari 28 indikator bullying fisik yang telah dirumuskan dalam penelitian ini muncul pada siswa SD, artinya hampir setengahnya indikasi bullying fisik dilakukan oleh siswa SD terhadap siswa lainnya (sesama teman), dengan indikator yang paling banyak muncul (terjadi) adalah "memukul" (65,5\%) dan "mencubit" $(65,5 \%)$, sedangkan indikator bullying fisik yang paling sedikit muncul "mencekik" (9,1\%); dan (2) Indikasi bullying fisik termasuk kepada perilaku buruk. Perilaku buruk ini dapat diubah menjadi perilaku baik melalui usaha pendidikan, yaitu pendidikan akhlak yang 
Dadang Kurnia \& Ani Nur Aeni, Indikasi Bullying Fisik pada Siswa SD...

bersumberkan kepada Al-Quran dan hadits. Pendidikan akhlak juga dilakukan untuk mencegah dan menghindarkan siswa dari perilaku bullying Sehingga dapat melahirkan siswa yang berakhlak karimah (mulia).

\section{REFFERENSI}

Adila, N. (2009). PENGARUH KONTROL SOSIAL TERHADAP PERILAKU BULLYING PELAJAR DI SEKOLAH MENENGAH PERTAMA. Jurnal Kriminologi Indonesia. 5 (1). 56-66.

Aeni, A. (2014). Pendidikan Karakter Untuk Mahasiswa PGSD. Bandung: UPI Press.

Aeni, A. (2014). PENDIDIKAN KARAKTER UNTUK SISWA SD DALAM PERSPEKTIF ISLAM. Mimbar Sekolah Dasar, 1 (1), 5058.

doi:http://dx.doi.org/10.17509/mimbarsd.vlil.863.

Aeni, A. (2017). Pendidikan Keteladanan Di Keluraga Pedagang Dan Karyawan Dan Implikasinya Terhadap Pembentukan Karakter Anak (Survey Pada lbu Yang Bekerja Sebagai Pedagang Dan Karyawan Di Sumedang). Dalam Julia, dkk. Prosiding Seminar Nasional Membangun Generasi Emas 2045 yang Berkarakter dan Melek IT dan Pelatihan Berpikir Suprarasional.

Al-Asqalani, I.H. (2010). Syarah Shahih AlBukhari. Jakarta: Pustaka Imam AsySyafi.

Ali, Z. (2007). Pendidikan Agama Islam. Jakarta: Bumi Aksara.

Anshari, E.S. (1993). Wawasan Islam. Jakarta: PT. Raja Grafindo Persada.

Astuti, P.R. (2018). Meredam Bullying: 3 Cara Efektif Mengatasi KPA (Kekerasan Pada Anak). Jakarta: Grasindo

Azwar. S. (2008). Sikap Manusia Teori dan Pengukurannya. Edisi ke-2. Yogyakarta: Pustaka Pelajar.

Batsche, G.M \& Knoff, H.M. (994). Bullies and Their Victims: Understanding a persuasive Problem in the schools. School Psychology Review, 23, 165-174.

Chomaria, N. (2013). 25 Perilaku anak dan Solusinya. Jakarta: PT. Alex Media Komputindo.

Coloroso. B. (2007). Stop Bullying. Jakarta: Serambi llmu Pustaka.
Dewi, N, Hasan, H, Mahmud. (2016). PERILAKU BULLYING YANG TERJADI DI SD NEGERI UNGGUL LAMPEUNEURUT ACEH BESAR. Jurnal Ilmiah Pendidikan Guru Sekolah Dasar FKIP Unsyiah. 1( 2), 37-45.

Dosen Psikologi (2018). Teori Bullying Dalam Psikologi yang Wajib Diketahui. https://dosenpsikologi.com/teoribullying-dalam-psikologi.

Espalge. at al (2014). School-Based Prevention of Peer Relationship Problem. New York: Oxford University.

Fahdini, R., Mulyadi, E., Suhandani, D., \& Julia, J. (2014). IDENTIFIKASI KOMPETENSI GURU SEBAGAI CERMINAN PROFESIONALISME TENAGA PENDIDIK DI KABUPATEN SUMEDANG. Mimbar Sekolah Dasar, 1(1), 33-42. doi:http://dx.doi.org/10.17509/mimbarsd.vli1.1362.

Fitria dan Aulia, R. (2016). FAKTOR-FAKTOR YANG BERHUBUNGAN DENGAN PERILAKU BULLYING. Idea Nursing Joumal. 7 (3). 9-17.

Fitriani, R.S. (2017). Peran Orang Tua Dalam Mencegah Cyberbulying. Dalam Sutarman dkk. (73-86). Prosiding Pada Seminar Nasional Pendidikan Mengatasi Bullying Melalui Penanaman Nilai-Nilai Kearifan Lokal Sebagai Upaya Memperkuat Pendidikan Karakter Bangsa.

Fuadi, F.Z. (2014). Menjewer Telinga Anak Antara Pendidikan, Kesehatan Dan Kejahatan.

http://farid.zainalfuadi.net/blog/2014/0 9/28/menjewer-telinga-anak-antarapendidikan-kesehatan-dan-kejahatan/

Gichara. J. (2018). Mengatasi Perilaku Buruk anak. Depok: Kawan Pustaka.

Giwangsa, S.F, Ikhsan, MT. H, Aminah, M. (2017). Problematika Perilaku Bullying Pada Anak. Dalam Sutarman dkk. (7386). Prosiding Pada Seminar Nasional Pendidikan Mengatasi Bullying Melalui Penanaman Nilai-Nilai Kearifan Lokal Sebagai Upaya Memperkuat Pendidikan Karakter Bangsa.

Hanjono, L. (2015). Trauma Akibat Bullying Di Sekolah.

http://www.limanharijono.com/traumaakibat-bullying-di-sekolah/

Infokabayan (2011). Berbahaya dan berakibat fatal jika bagian tubuh ini dipukul.

http://infokabayan.blogspot.com/201 1/04/ber bahaya-dan-berakibat-fatal-jika.html. 
Kustanti, E. (2015). GAMBARAN BULLYING PADA PELAJAR DI KOTA SEMARANG. Jurnal Psikologi, 14(1), 2939.

doi:http://dx.doi.org/10.14710/ipu.14.1.2 9-39.

Majid, A \& Andayani, D. (2012). Pendidikan Karakter Perspektif Islam. Bandung: PT. Remaja Rosdakarya.

Olweus. D. (1993). Bullying at School: What We know and What We Can Do. Cambridge: MA. Blackwell.

Olweus. D. (2006). Bullying in School: Facts and Intervension. Norwegia: Research Centre for Healt Promotion, University of Bergen.

Pumama. D. (2010) Cermat dalam Memilih Sekolah yang Tepat. Jakarta: Gagas Media.

Righby. K. (1996). Bulluying in School and what to do it. London: Jessica Kingley.

Rusyan, T. (Tt). Pendidikan Budi Pekerti. Jakarta: PT. Inti Media Ciptanusantara.

Santrock. J.W. (2012). Life-SPAN Development. Perkembangan Masa Hidup. Jilid I. Jakarta: Erlangga.

Sauri (2011). Filsafat dan Teosofat Akhlak. Bandung: Rizqi Press.

Sugojokanto, S. (2014). Mencegah Kekerasan Pada Anak. Jakarta: PT. Alex Media Komputindo.

Supriani dan Sari. E.P. (2017). FAKTOR YANG MEMPENGARUHI BULLYING PADA ANAK USIA SEKOLAH DI SEKOLAH DASAR KECAMATAN SYIAH KUALA BANDA ACEH. Idea Nursing Joumal. 8 (3).

Suresman, E. (2006). Pendidikan Agama Islam di Perguruan Tinggi. Jakarta: Emas Yayasan Pena.

Syah, M. (2007). Psikologi Belajar. Jakarta: PT. Raja Grafindo Persada.

Theo dan Watiek. (2016). Aku anak yang berani, bisa melindungi diri 2. Jakarta: PT. Gramedia Pustaka Utama.

Tim Dosen PAl. (2003). Islam: Doktrin dan Dinamika Umat. Bandung: Value Press.

Tim Dosen PAl. (2008). Islam: Tuntunan dan Pedoman Hidup.. Bandung: Value Press.

Tim Penyusun Kamus. (2005). Kamus Besar Bahasa Indonesia. Jakarta: Balai Pustaka.

Tim Yayasan Sejiwa. (2008). Bullying: Mengatasi Kekerasan di Sekolah dan Lingkungan Sekitar Anak. Jakarta: Gramedia.
Wikjpedia. (2018). Penindasan. https://id.wikipedia.org/wiki/Penindasa n.

Zuriah. N. (2007). Pendidikan Moral \& Budi Pekerti Dalam Perspektif Perubahan. Jakarta: Bumi Aksara. 